\title{
Standardization of beejakarishta preparation with respect to seasonal changes and the determination of its antibacterial activity against selected clinical isolates
}

\author{
K.P. Shamna*, A.K. Muraleedharan* and Muhammad Musthafa Poyil \\ Department of Iatrochemistry and Pharmaceutics, M.V.R Ayurveda Medical College, Kannur-670563, India \\ *Department of Basic Medical Sciences, College of Medicine, Prince Sattam bin Abdulaziz University, Al-Kharj, 11942, Saudi Arabia
}

\section{Article Info}

\section{Article history}

Received 12 April 2021

Revised 29 May 2021

Accepted 30 May 2021

Published online 30 June 2021

\section{Keywords}

Beejakarishta

Sandhana kala

Fermentation tests

Antibacterial activity

Multi drug resistant (MDR)

Bacteria

\begin{abstract}
Beejakarishta is an 'arishta' (self-generated alcoholic) preparation in Ayurveda with a wide range of pharmacological applications including in digestive disorders, anaemia, piles, inflammation, urinary tract infections (UTIs), diabetes, jaundice, etc. Even though, there are many studies which show the effect of different containers and method of preparation in the fermentation process of different arishta-asavas (fermented ayurvedic potion); no studies have been conducted to analyse the effect of different seasons and different time duration on the physicochemical characteristics and pharmacological potentials of beejakarishta. So, present study investigated the effect of season and duration in fermentation process of beejakarishta and variation in their analytical properties. In this study, six samples are made in April (summer season-greeshmaritu), October (autumn season - sarataritu) and in January (winter season -sisiraritu). In each season, three samples each were kept for 10 days fermentation and for 20 days fermentation. Fermentation tests and physicochemical analysis were carried out for all the samples and compared. HPTLC analysis was performed to evaluate the compounds present in the test samples. Beejakarishta with 20 days fermentation in summer season $\left(\mathrm{BAG}_{20}\right)$, which showed typical physicochemical properties is examined for antibacterial analysis. $100 \mu 1$ of $\mathrm{BAG}_{20}$ showed significant antibacterial activity against Escherichia coli $(18 \mathrm{~mm})$, Staphylococcus aureus $(19 \mathrm{~mm})$ and Klebsiella pneumonia $(26 \mathrm{~mm})$. From the study, it was confirmed, seasons have a greater impact in determining the properties of the beejakarishta. The $\mathrm{BAG}_{20}$ can be developed as an effective novel antibacterial drugs for treatment of multidrug resistant (MDR) infection.
\end{abstract}

\section{Introduction}

Bhaishajyakalpana is the pharmaceutical branch dealing with various types of medicinal preparation as reported in ayurveda. Sandhanakalpana (biomedical fermentation) is a unique dosage form of ayurvedic pharmaceutics. It comes under secondary preparations which are based on primary formulations like swarasa (juices) kwatha (decoctions) etc. Sandhana is a process, in which liquid preparations either along with medicines or food materials are kept in a vessel for long duration to facilitate the fermentation process (Yadavji Trikamji, 1983). Based on the end product formed, sandhanakalpana is divided in to madyakalpana (where the end-products are alcoholic preparations like arishta, asava, etc.) and shukatakalpana (where the endproducts are the preparations of acidic nature like dhanyamla). Among these, arishta is said to be superior as its unique combination of drugs and processing (Krishnamurthy, 1973). These formulations have longer shelf life, quick absorption and action and excellent therapeutic efficacy (Parasurama Sastri, 2008).

Beejakarishta has been recommended in wide range of clinical conditions like digestive disorders, anaemia, piles, inflammation,

Corresponding author: Mr. Muhammad Musthafa Poyil
Department of Basic Medical Sciences, College of Medicine, Prince
Sattam Bin Abdulaziz University, Al-Kharj, 11942, Saudi Arabia
E-mail: pmusthu@gmail.com
Tel.: +96-6565634412

Copyright () 2021 Ukaaz Publications. All rights reserved.

Email: ukaaz@yahoo.com; Website: www.ukaazpublications.com urinary tract infections (UTIs), diabetes, jaundice, etc. (Sre Ganga Sahya Pandeya, 2003). Even though, various Acharyas explained different seasons and time periods, most of the references of beejakarishta explain fermentation period as ten days in summer season and 20 days in winter season (Srikantha Murthy 1984; Murthy Srikantha, 2009 and Sharma Ram Anant, 2012).

Fermentation process depends upon many factors like nature and quantity of the ingredients, methods of preparation, the containers for fermentation, place of fermentation, seasons, duration of fermentation, etc. (Harisankar Pandey, 1993). Among these, duration of fermentation and seasons have a major role in progress of fermentation. There are studies which show the effect of different containers and method of preparation over the fermentation process of different arishtas and asavas, but no study has been conducted with respect to duration and seasonal effect. The duration for fermentation vary from formulation-to-formulation and in general, 30 days is explained in classic fermentations with some exceptions. In beejakarishta, it is specified that, ten days in summer and 20 days in winter are the optimal durations. This indicates season has a role to determine the duration of fermentation and in classical references, the months of January and February are considered as winter (sisira), April and May as summer (greeshma) and October and November as autumn (sarat) (Sir Monier-Williams, 1899, Visvanatha Dvivedi Shastri, 2002). 
The wide spread of multidrug resistant (MDR) bacteria is one of the global challenges of the $21^{\text {st }}$ century. MDR microbes are generally resistant to three or more antibiotics. Despite of the development of new antibacterial agents, the past three decades have been witnessing for an increase in resistance against drugs by bacteria. In general, bacteria have the genetic ability to transmit and acquire resistance to drugs, which are utilized as therapeutic agents. Thus, there is a need for development of new antibacterial agents from different sources (Elbossaty, 2017; Aslam et al., 2018).

The present study examines, the changes in beejakarishta prepared in different seasons with different duration of fermentation (10 and 20 days) and determines the antibacterial activity of the most efficient sample against four of the clinically isolated pathogens, viz. Escherichia coli, Staphylococcus aureus, Klebsiella pneumonia and

Table 1: Ingredients of decoction (kashaya)
Acinetobacter baumannii. Fermentation tests and physicochemical analysis were carried out for all the samples and compared. HPTLC analysis was performed to evaluate the compounds present in the test samples.

\section{Materials and Methods}

\subsection{Collection of raw materials for the study}

The major ingredients (Table 1) were collected from raw drug unit of MVR ayurvedic pharmacy and authenticated by Department of Pharmacology, MVR Ayurveda Medical College, Kannur. Honey was collected from Eramam, Kannur and subjected to different analytical parameters. Raw brown sugar was collected from farmers at Bangalore, Erode and Coimbatore and the quality was confirmed before the usage.

\begin{tabular}{|c|l|l|l|c|}
\hline SI. No. & Ingredient & Scientific name & Part used & Quantity taken for the preparation of 1 sample \\
\hline 1 & Asana & Pterocarpus marsupium & Heart wood & $256 \mathrm{~g}$ \\
\hline 2 & Hareethaki & Terminalia chebula & fruit & $106 \mathrm{~g}$ \\
\hline 3 & Vibheethaki & Terminalia bellirica & Fruit & $106 \mathrm{~g}$ \\
\hline 4 & Amalaki & Phyllanthusemblica & Fruit & $106 \mathrm{~g}$ \\
\hline 5 & Draksha & Vitisvinifera & Fruit & $80 \mathrm{~g}$ \\
\hline 6 & Laksha & Lacciferlacca & Resin & $112 \mathrm{~g}$ \\
\hline 7 & Water & & & 4 lit \\
\hline
\end{tabular}

\subsection{Preparation of beejakarishta}

\subsubsection{Poorva karma (pre-procedure)}

Six glazed porcelain jars of three-liter capacity were taken. Each were cleaned thoroughly and dried under hot sun for two days. The inside of jar is then fumigated using sandal, vetiver, camphor, long pepper, spikenard and pepper. Then, the inner surface of the vessels was smeared with ghee and kept aside. For condiments (Table 2), the drugs were taken in required quantity and separately pounded in mortar to a coarse powder

\subsubsection{Pradhana karma (main procedure)}

The required drugs (as given in the Table2) were properly cleaned and dried. They were pounded to coarse powder separately. The drugs were put in a steel vessel. 1 liter of water was added and the level of water was noted. Then, 3 more liters of water added, placed on mild fire, boiled, frequently stirred till the water reduced to $1 / 4^{\text {th }}$. Then, it was strained and cooled to room temperature. Sugar was added little-by-little and dissolved completely. Then, it was strained through a cloth followed by the addition of honey and thoroughly

Table 2: Ingredients of condiments (prakshepa) mixed. The mixture is poured carefully into the prepared container. It is filled up to three fourth capacity of the container. Condiments are added and stirred well. The mouth of container is closed with a piece of cloth, and then the lid is placed above that. Sealing is done by winding a three layered cloth around joint which is smeared with clay (Figures 1 to 5).

\subsubsection{Paschat karma (following procedure)}

The filled containers were kept in a cardboard box filled with barley up to the neck portion. Following the same procedure, six samples are prepared in summer, autumn and winter seasons. Fermentation tests were observed by changes in state of prak sepakadravya (condiments) effervescence, hissing sound, alcoholic odor and taste, burning candle test, lime water test. In each season, 3 samples were kept for ten days fermentation, and on $11^{\text {th }}$ day they were opened and the product was filtered through a starch free muslin cloth. Other 3 samples were kept for 20 days fermentation and on $21^{\text {st }}$ day they were opened and filtered. The products were then subjected to physicochemical analysis (Figures 6 to 8 ).

\begin{tabular}{|c|l|l|l|c|}
\hline SI.No. & Ingredients & Scientific name & Part used & Quantity taken for the preparation of 1 sample \\
\hline 1 & Nagara & Zingiber officinale & Rhizome & $4 \mathrm{gm}$ \\
\hline 2 & Maricha & Piper nigrum & Fruit & $4 \mathrm{gm}$ \\
\hline 3 & Pippali & Piper longum & Fruit & $4 \mathrm{gm}$ \\
\hline 4 & Vyaghranagha & Capparis zeylanica & Plant & $4 \mathrm{gm}$ \\
\hline 5 & Usheera & Vetiveria zizanioides & Root & $4 \mathrm{gm}$ \\
\hline 6 & Kramuka & Areca catechu & Fruit & $4 \mathrm{gm}$ \\
\hline 7 & Elavaluka & Prunus cerasus & Fruit & $4 \mathrm{gm}$ \\
\hline 8 & Madhooka & Madhuca longifolia & Flower & $4 \mathrm{gm}$ \\
\hline 9 & Kushta & Saussure acostus & Root & $4 \mathrm{gm}$ \\
\hline
\end{tabular}




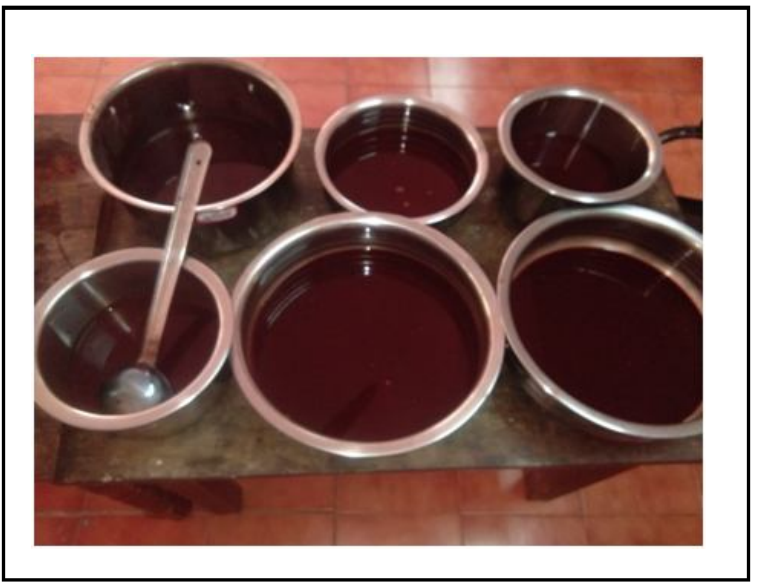

Figure 1: Kashaya Preparation.

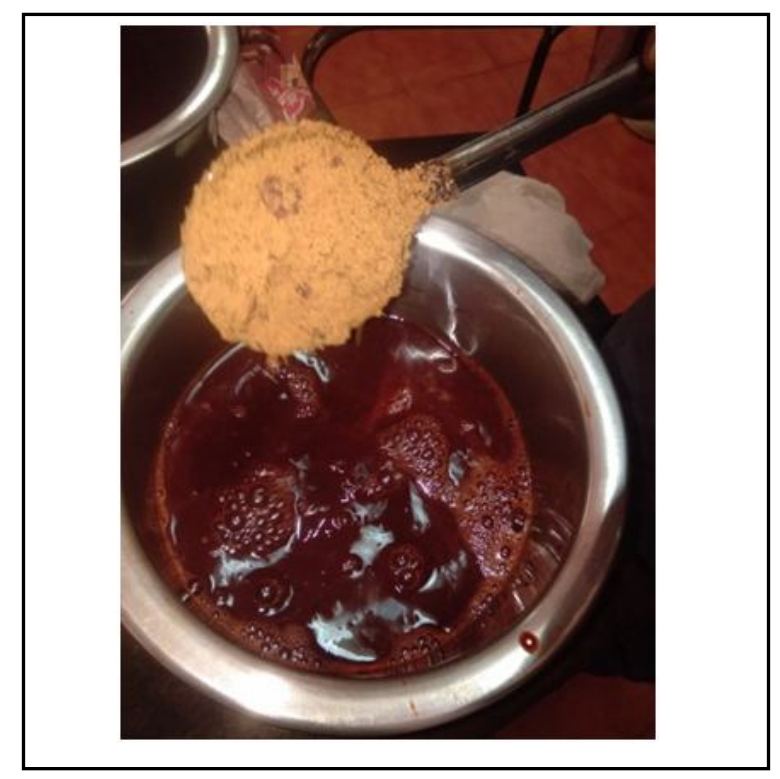

Figure 2: Adding sharkara.

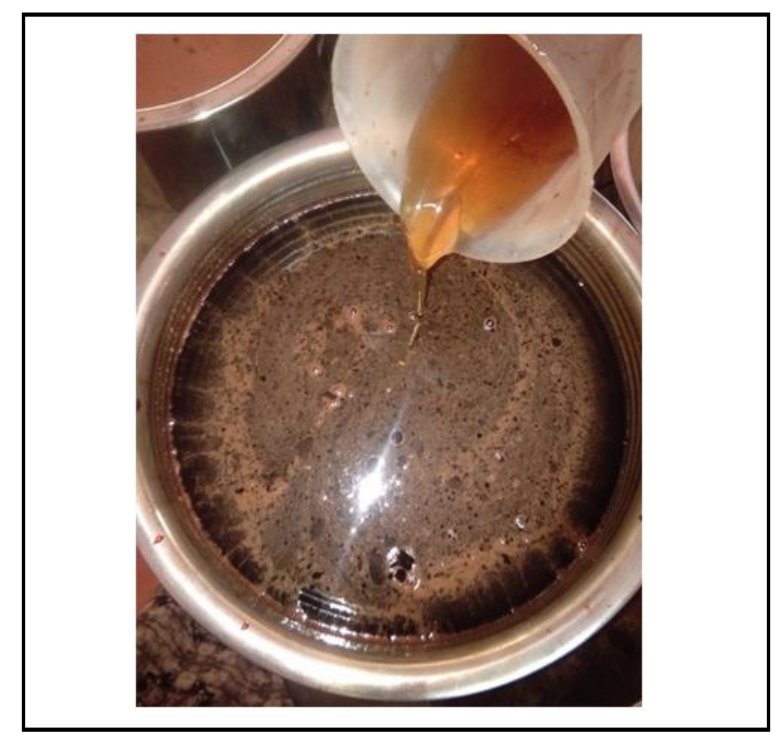

Figure 3: Adding kshuodra.

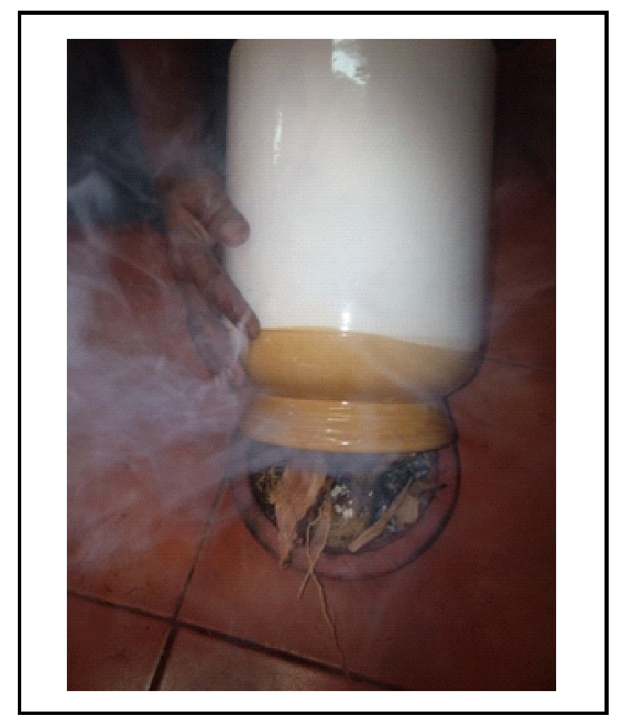

Figure 4: Dhupana of vessel.

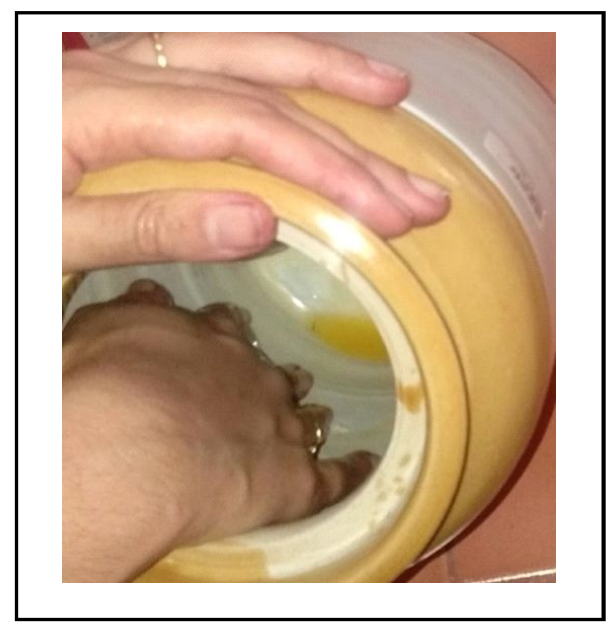

Figure 5: Ghritalepana.

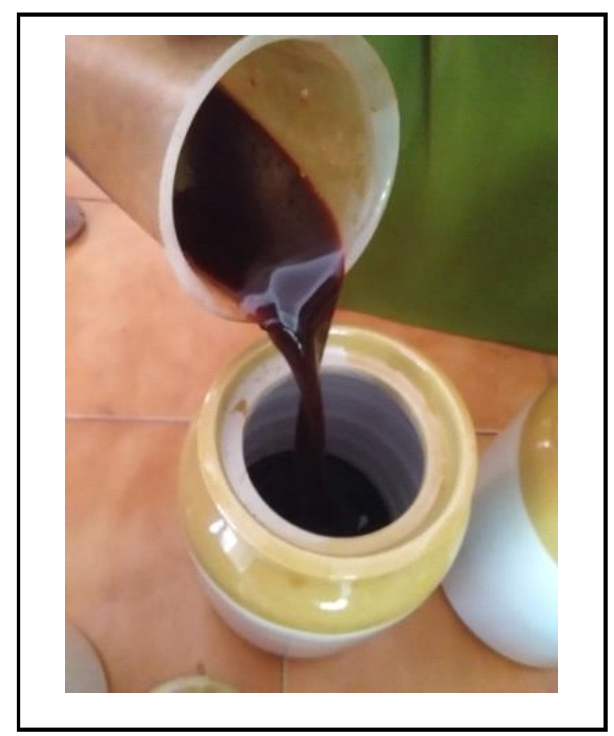

Figure 6: Transferring to the container. 


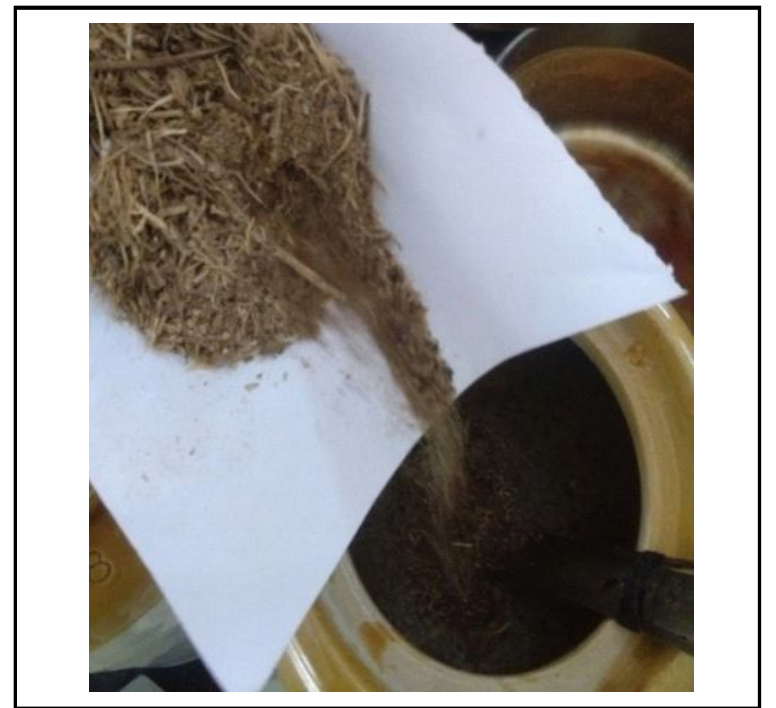

Figure 7: Adding prakshepa.

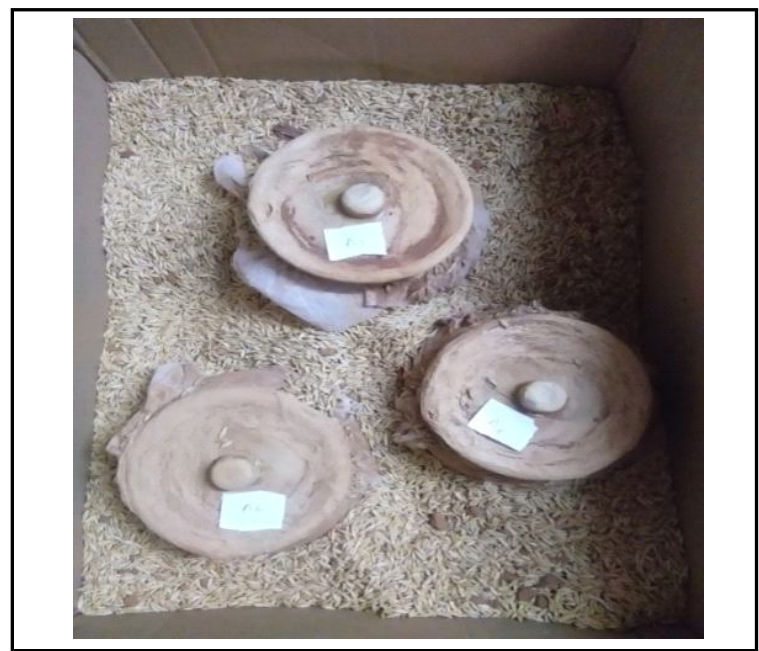

Figure 8: Placing for sandhana.

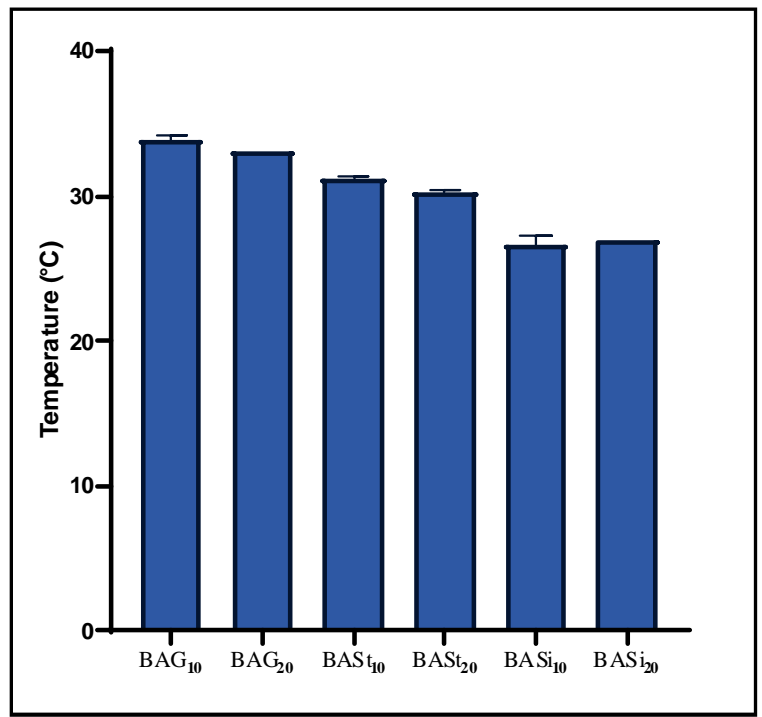

Figure 9: Analysis of temperature.

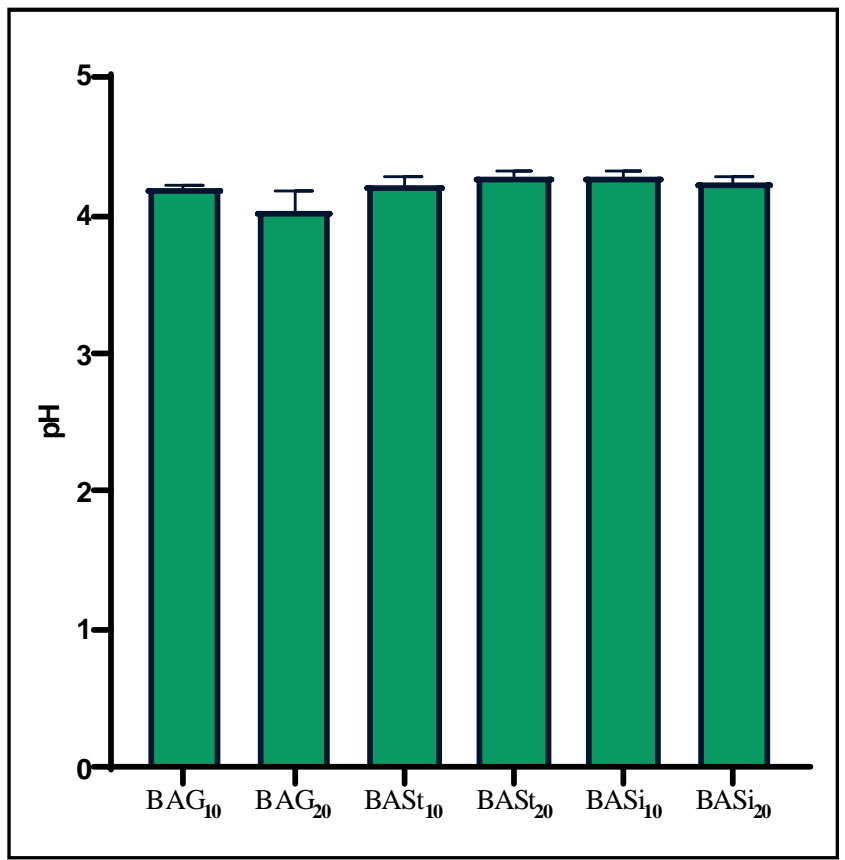

Figure 10: Analysis of $\mathrm{pH}$.

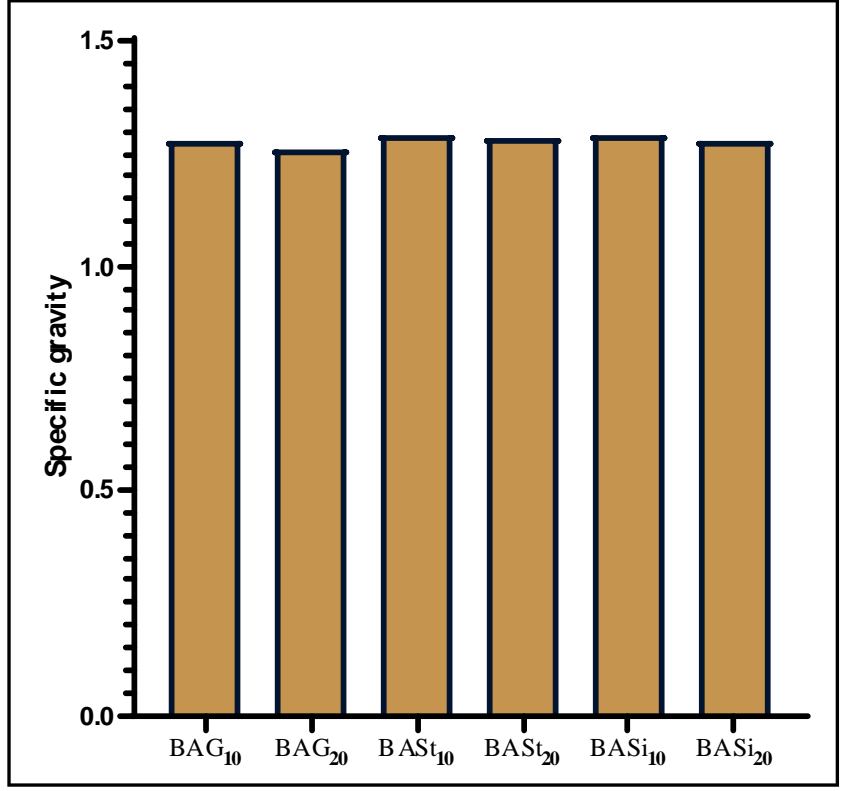

Figure 11: Analysis of specific gravity.

\subsection{Analysis of beejakarishta}

The prepared samples of beejakarishta were analyzed for its physical and chemical properties. The physical tests included burning candle test, lime water test, temperature, $\mathrm{pH}$, specific gravity, total solids, brix, alcohol content, etc., and the chemical tests included total sugar, reducing sugar, non-reducing sugar, total acidity, etc.

2.4 High performance thin layer chromatography (HPTLC) analysis

The analysis was performed at win CATS Planar Chromatography Manager, CAReKeralam Ltd., Thrissur, India. $10 \mathrm{ml}$ of test sample 
was partitioned in a separating funnel with $20 \mathrm{ml}$ of methanol extract. The hexane soluble portion was evaporated at room temperature to a volume of $1 \mathrm{ml} .8 \mu \mathrm{l}$ and $12 \mu \mathrm{l}$ of above sample was applied on a pre-coated silica gel on aluminum plates to a band width of $8 \mathrm{~mm}$ using Linomat 5 TLC applicator. The plate was developed in toluene ethyl acetate $(8: 2)$ and the developed plates were visualized under UV $254 \mathrm{~nm}, 366 \mathrm{~nm}$. The data like Rf values, densitometric scan, colors of the spots, etc., were observed and recorded.

Table 3: Description of samples

\begin{tabular}{|c|l|l|l|l|}
\hline Sl.No. & $\begin{array}{l}\text { Time duration } \\
\text { and season }\end{array}$ & Sample 1 & Sample2 & Sample3 \\
\hline 1 & 10 days in summer & $\mathrm{BAG}_{10} 1$ & $\mathrm{BAG}_{10} 2$ & $\mathrm{BAG}_{10} 3$ \\
\hline 2 & 20 days in summer & $\mathrm{BAG}_{20} 1$ & $\mathrm{BAG}_{20} 2$ & $\mathrm{BAG}_{20} 3$ \\
\hline 3 & 10 days in autumn & $\mathrm{BASt}_{10} 1$ & $\mathrm{BASt}_{10} 2$ & $\mathrm{BASt}_{10} 3$ \\
\hline 4 & 20 days in autumn & $\mathrm{BASt}_{20} 1$ & $\mathrm{BASt}_{20} 2$ & $\mathrm{BASt}_{20} 3$ \\
\hline 5 & 10 days in winter & $\mathrm{BASi}_{10} 1$ & $\mathrm{BASi}_{10} 2$ & $\mathrm{BASi}_{10} 3$ \\
\hline 6 & 20 days in winter & $\mathrm{BASi}_{20} 1$ & $\mathrm{BASi}_{20} 2$ & $\mathrm{BASi}_{20} 3$ \\
\hline
\end{tabular}

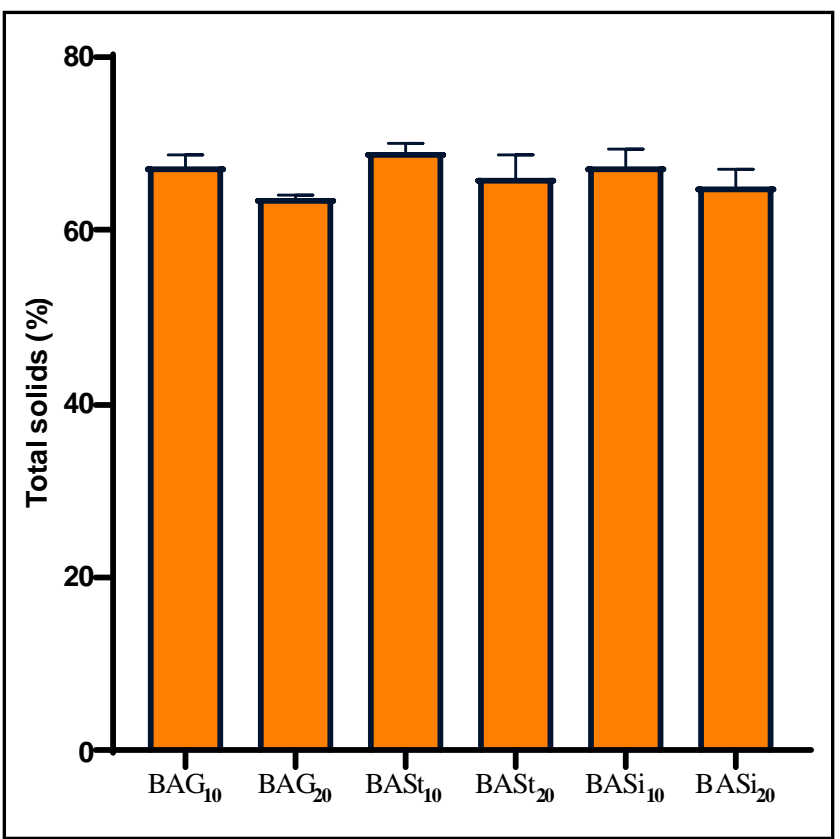

Figure 12: Analysis of total solids.

\subsection{Antibacterial analysis}

The prepared beejakarishta was subjected to antibacterial activity against hospital acquired pathogens. Antibacterial activity was determined by using well diffusion method (Rajesh et al., 2014) against Escherichia coli, Staphylococcus aureus, Klebsiella pnerumoniae and Acenitobacter bauumanni. Briefly, nutrient agar plates were prepared and overnight cultures of test organisms were swabbed over the plates. $6 \mathrm{~mm}$ well borer was used to bore wells. 3 concentrations of the samples were added to each well and other well was loaded with standard drug (ciprofloxacin). The plates were incubated at $37^{\circ} \mathrm{C}$ for $48 \mathrm{~h}$. After incubations, the plates were observed for inhibitory zones. The zones were measured in millimetres.

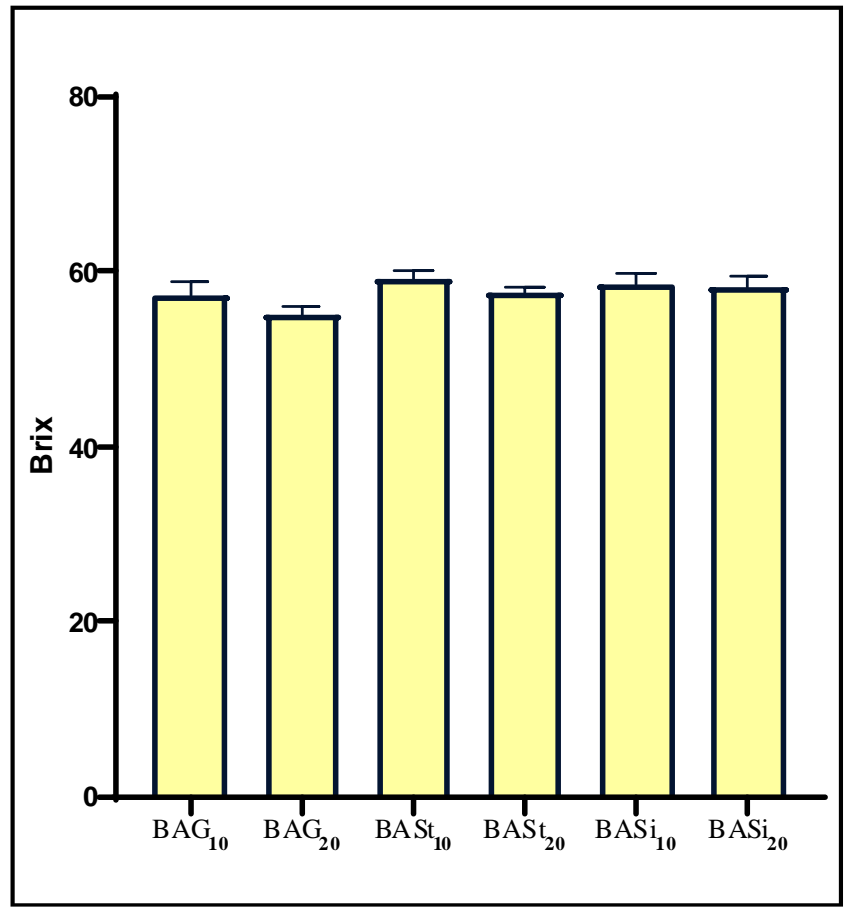

Figure 13: Analysis of brix.

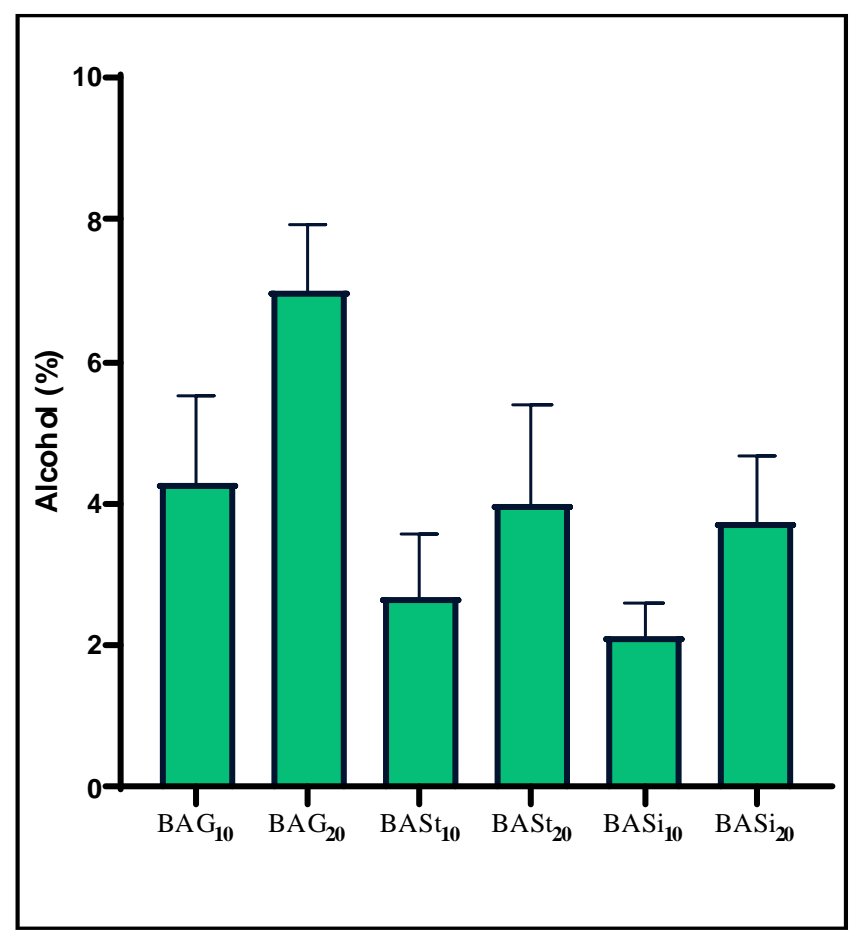

Figure 14: Analysis of alcohol content.

\section{Results}

Fermentation analysis, floating of praksepakadravya (Table 3) condiments - effervescence, hissing sound, burning candle test, lime water test. The fermentation analysis included the steps described below. 
Table 4: Comparison of $\mathrm{Rf}$ values and area percentages of the samples

\begin{tabular}{|c|c|c|c|c|c|c|}
\hline & G-10 & G-20 & ST-10 & ST-20 & SI-10 & SI-20 \\
\hline-0.07 & $+(91.81 \%)$ & & & $+(88.76 \%)$ & $+(88.12 \%)$ & $+(87.47 \%)$ \\
\hline-0.06 & & $+(86.32 \%)$ & $+(85.16 \%)$ & & & \\
\hline 0.06 & & & & & $+(8.49 \%)$ & $+(9.76 \%)$ \\
\hline 0. 07 & & & $+(10.37 \%)$ & $+(10.51 \%)$ & & \\
\hline 0. 09 & & $+(8.72 \%)$ & & & & \\
\hline 0. 10 & $+(6.20 \%)$ & & & & & \\
\hline 0.59 & & & & & $+(3.39 \%)$ & \\
\hline 0.62 & & & & & & $+(2.77 \%)$ \\
\hline 0.64 & & $+(0.93 \%)$ & & & & \\
\hline 0. 71 & & & & $+(1.73 \%)$ & & \\
\hline 0.95 & & & $+(4.46 \%)$ & & & \\
\hline 0. 97 & & $+(4.03 \%)$ & & & & \\
\hline 0. 99 & $+(2.00 \%)$ & & & & & \\
\hline
\end{tabular}

The plus sign indicates the presence of a peak in the range mentioned. The percentage values with respect to their concentrations have been provided in brackets. Left column lists the Rf values.

Table 5: Antibacterial activity of beejakarishta (20 days'/summer season)

\begin{tabular}{|c|l|c|cc|c|}
\hline \multirow{2}{*}{ SI.No. } & \multirow{2}{*}{ Test organisms } & \multicolumn{4}{|c|}{ Inhibitory zones $(\mathbf{m m})$ against quantities } \\
\cline { 3 - 6 } & & $\mathbf{2 5} \boldsymbol{\mu \mathbf { l }}$ & $\mathbf{5 0} \boldsymbol{\mu l}$ & $\mathbf{1 0 0} \boldsymbol{\mu l}$ & Std. drug \\
\hline 1 & Escherichia coli & - & - & 18 & 24 \\
2 & Staphylococcus aureus & - & 15 & 19 & 21 \\
3 & Klebsiella pneumonia & - & 10 & 26 & 29 \\
4 & Acenitobacter bauumanni & - & - & - & 23 \\
\hline
\end{tabular}

\subsection{Floating of praksepakadravya (condiments)}

By fermentation aqueous media change to alcoholic media which is less dense than water. So, the sunken condiments indicate the production of alcohol. All the samples in summer season, autumn and winter season showed floating of condiments from $0^{\text {th }}$ day to $11^{\text {th }}$ day. Summer season samples gradually began to sink and on $21^{\text {st }}$ day in $\mathrm{BAG}_{20} 1$ and in $\mathrm{BAG}_{20} 2$ condiments were partially sunken, and in $\mathrm{BAG}_{20} 3$, they were mostly sunken. On $21^{\text {st }}$ day, in autumn season and winter season, the condiments partially floated and partially sunken in all samples which indicated the production of alcohol.

\subsection{Effervescence}

The formation of $\mathrm{CO}_{2}$ during process caused bubbling in the liquid and was observed in $5^{\text {th }}$ and $11^{\text {th }}$ day, analysis of summer season samples. On $11^{\text {th }}$ day large bubbles were seen, showing progress of fermentation. On reaching $20^{\text {th }}$ day, no effervescence in $\mathrm{BAG}_{20} 1$ and 3 sample and decreased considerably in $\mathrm{BAG}_{20} 2$. In autumn and in winter samples, the effervescence was present on $5^{\text {th }}, 11^{\text {th }}$ and $21^{\text {st }}$ days but decreased in $\mathrm{BASt}_{20}$ samples.

\subsection{Hissing sound}

The formation of $\mathrm{CO}_{2}$ makes the hissing sound in summer season samples, it was absent in $0^{\text {th }}$ day but pre sent in $5^{\text {th }}$ day and $11^{\text {th }}$ day, and again absent in $21^{\text {th }}$ day, indicating gradual progression and completion of fermentation. Inautumn season samples, it was present in $11^{\text {th }}$ day and $21^{\text {st }}$ day but decreased in $21^{\text {st }}$ day. In winter season, hissing sound was absent in $0^{\text {th }}, 5^{\text {th }}$ day but present in $11^{\text {th }}$ day and $21^{\text {st }}$ day, indicating continuation of fermentation.

\subsection{Burning candle test}

In summer season and autumn season, burning candle was put off in $5^{\text {th }}$ day and $11^{\text {th }}$ day, but continues to burn on $21^{\text {st }}$ day. In $\mathrm{BASt}_{20} 3$, it was put off in $21^{\text {st }}$ day. In winter season, candle continued to burn $5^{\text {th }}$, and put off on $11^{\text {th }}$ and $21^{\text {st }}$ day. During the process of fermentation, burning candle got extinguished if taken near to the fermentation liquid surface. This was because of the production of $\mathrm{CO}_{2}$ by fermentation. After completion of fermentation, the candle continued to burn since there was no $\mathrm{CO}_{2}$ produced. During the process of fermentation, burning candle get extinguished if taken near to the fermentation liquid surface. This is because of the production of $\mathrm{CO}_{2}$ by fermentation. After completion of fermentation, since no $\mathrm{CO}_{2}$ is produced the candle continues to burn. 


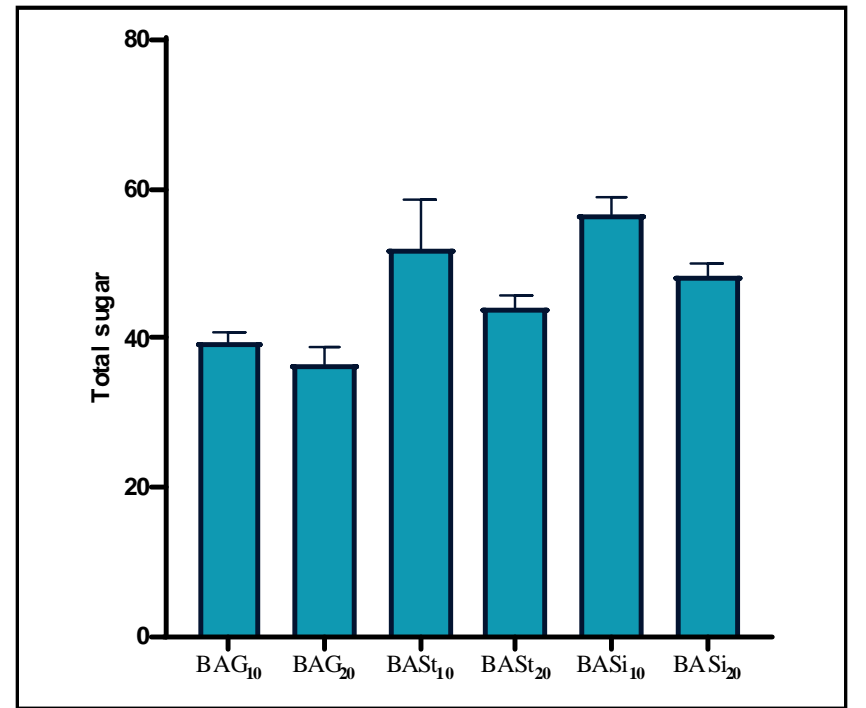

Figure 15: Analysis of total sugar.

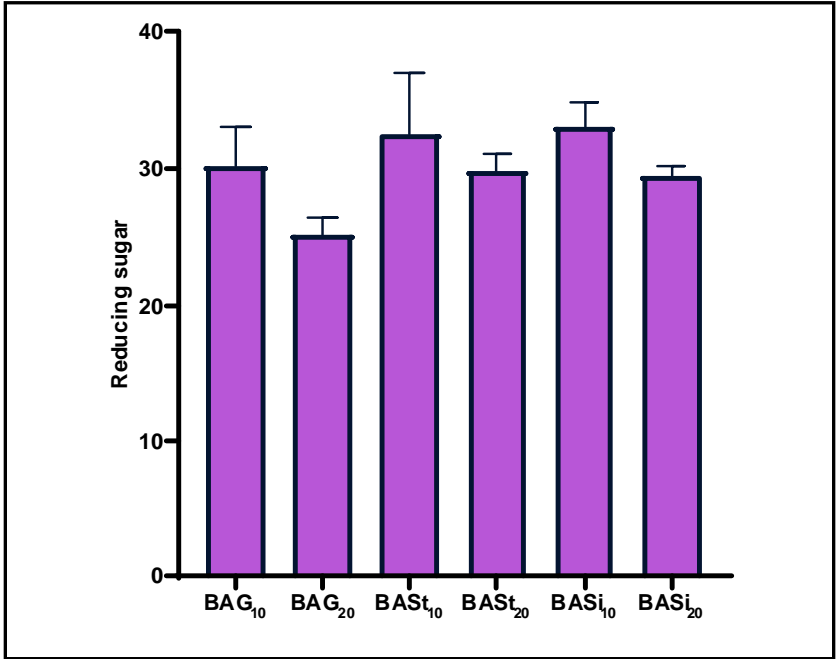

Figure 16: Analysis of reducing sugar.

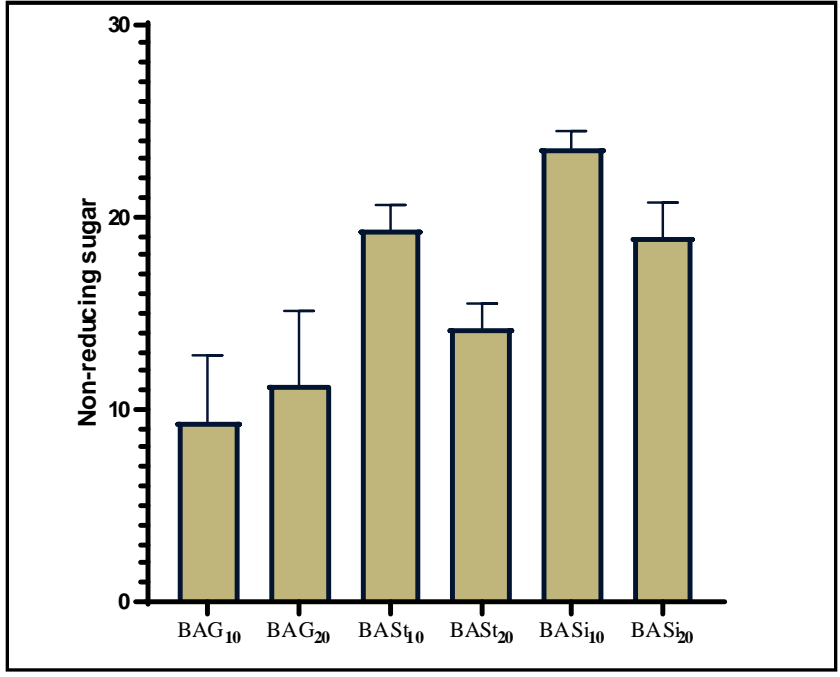

Figure 17: Analysis of non-reducing sugar.

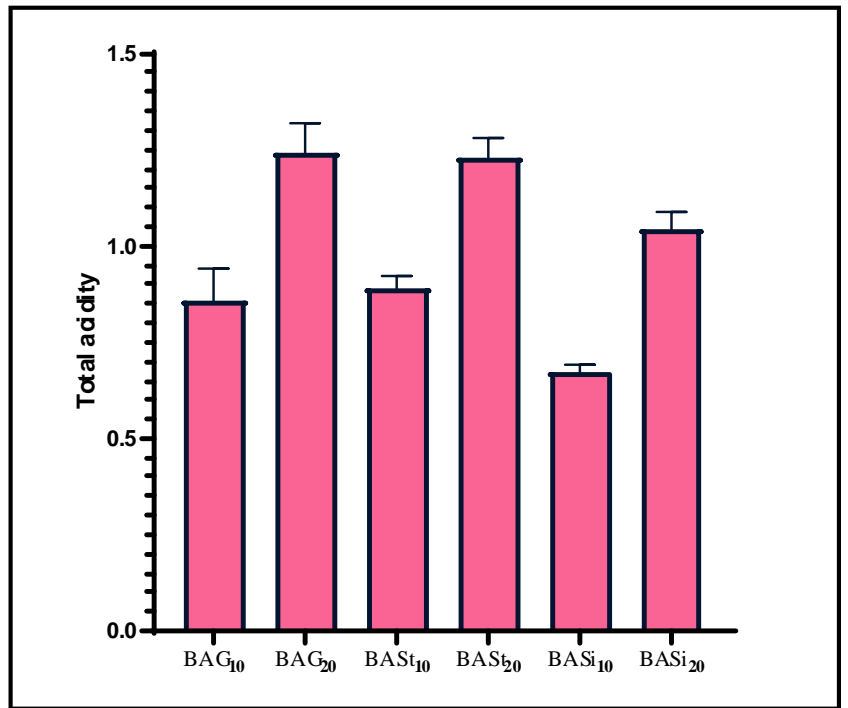

Figure 18: Analysis of total acidity.

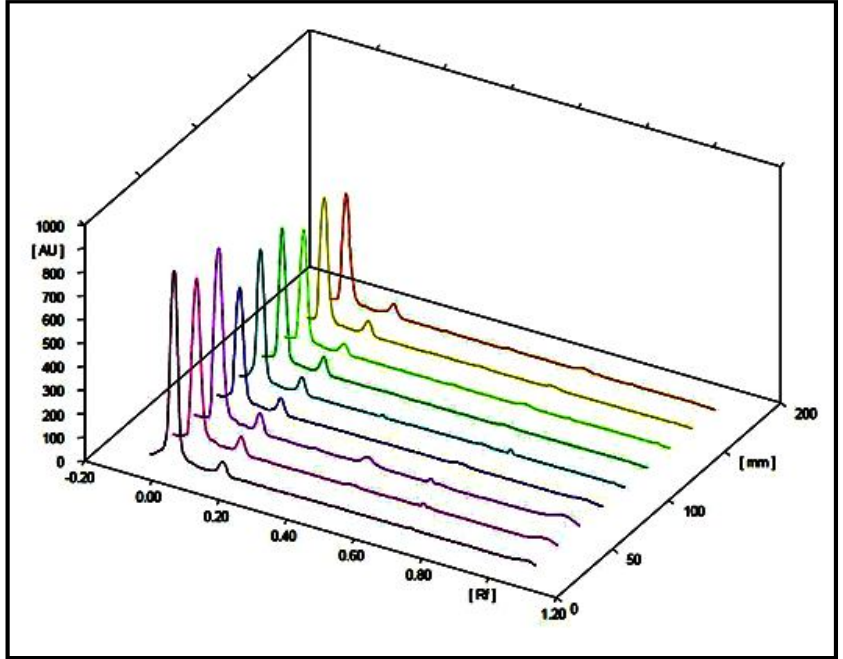

Figure 19: Graphical representation of overall track analysis.

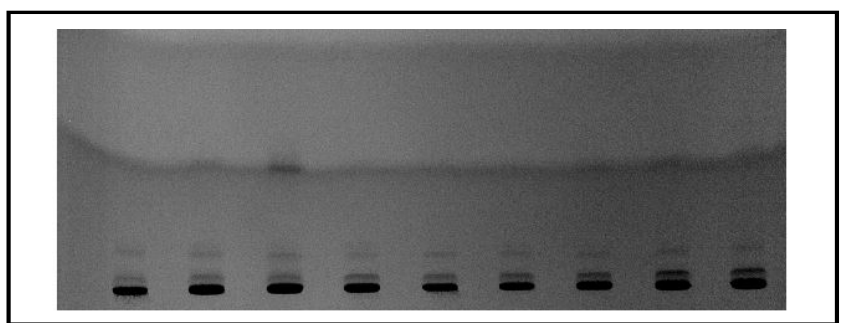

Figure 20: Observation at $254 \mathrm{~nm}$.

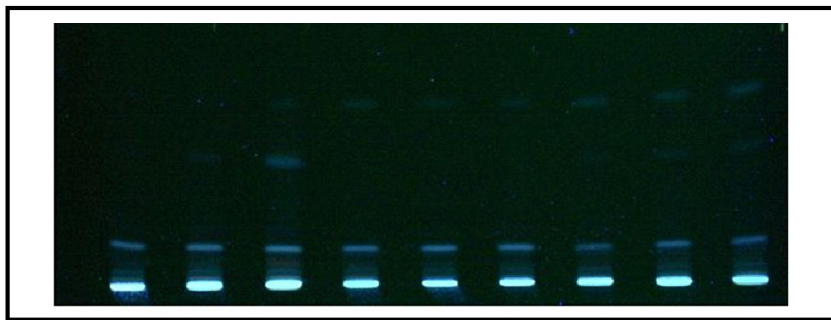

Figure 21: Observation at $366 \mathrm{~nm}$. 


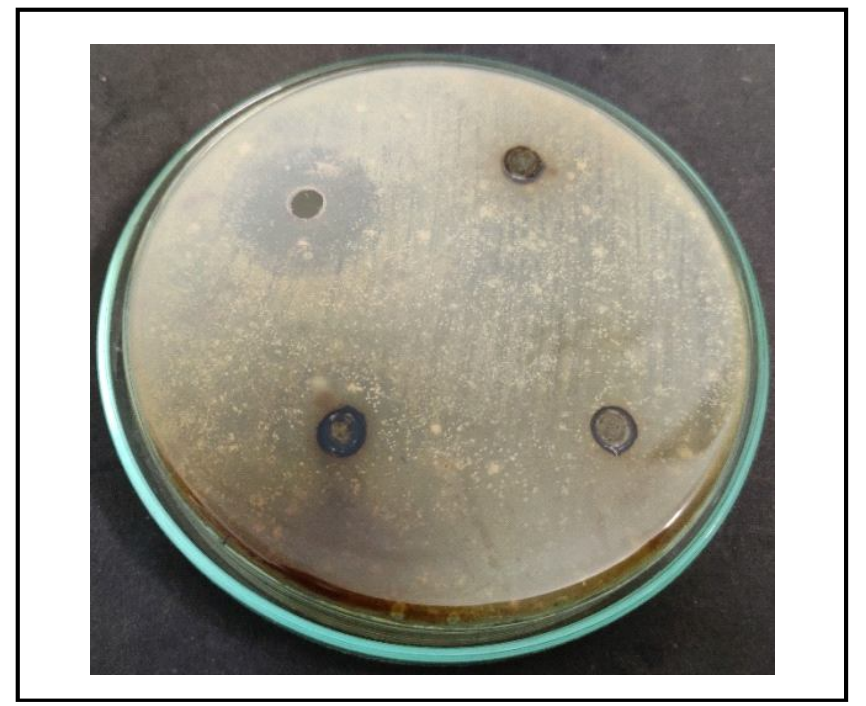

Figure 22: ABA against E. coli.

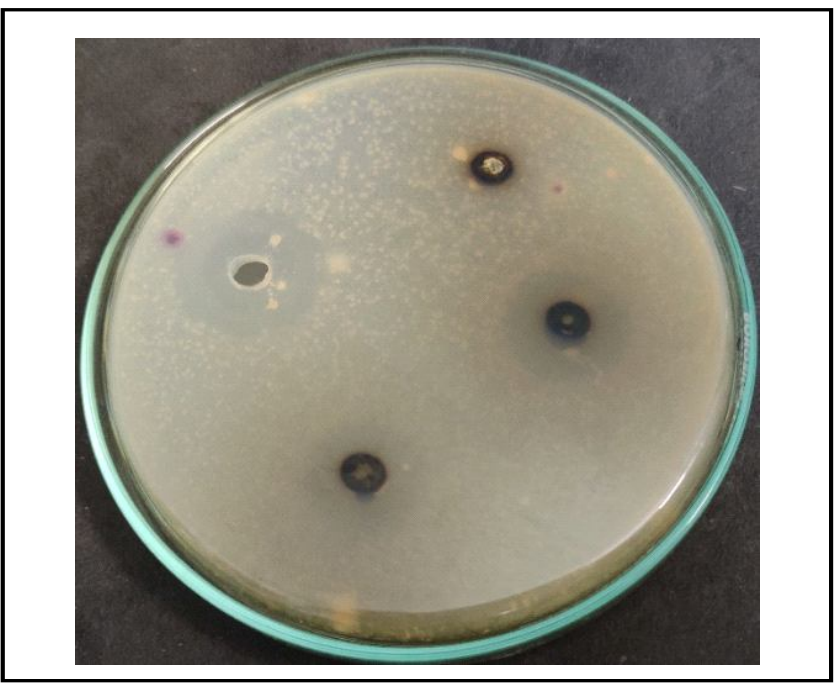

Figure 23: ABA against $S$. aureus.

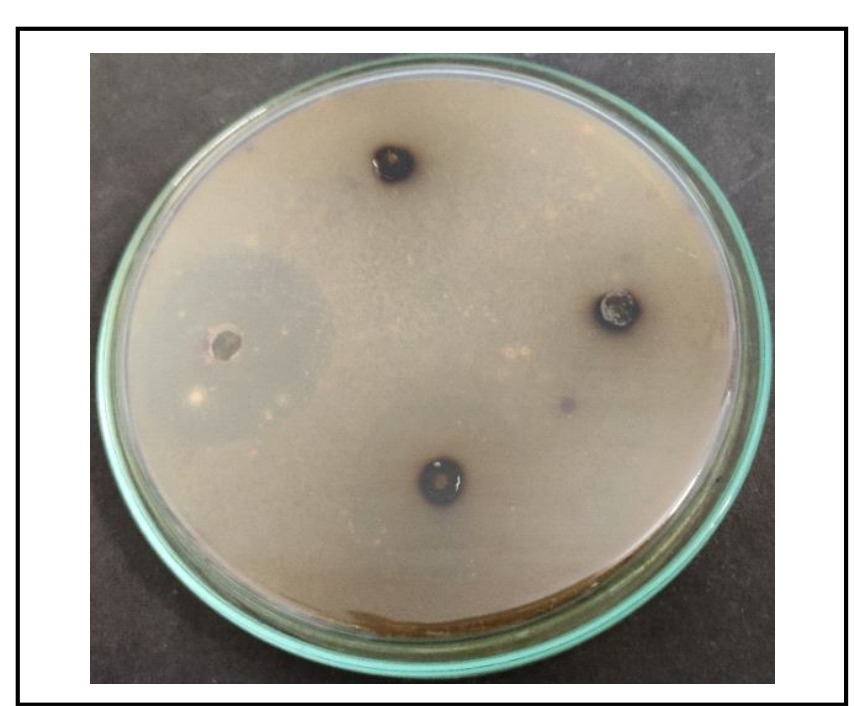

Figure 24: ABA against $K$. pneumoniae.

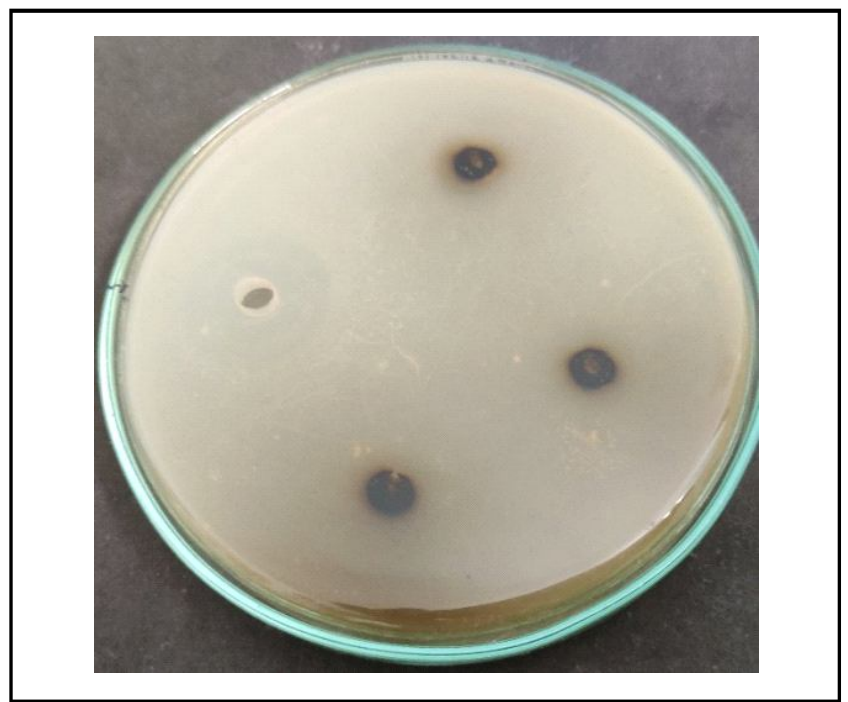

Figure 25: ABA against A. baumanni.

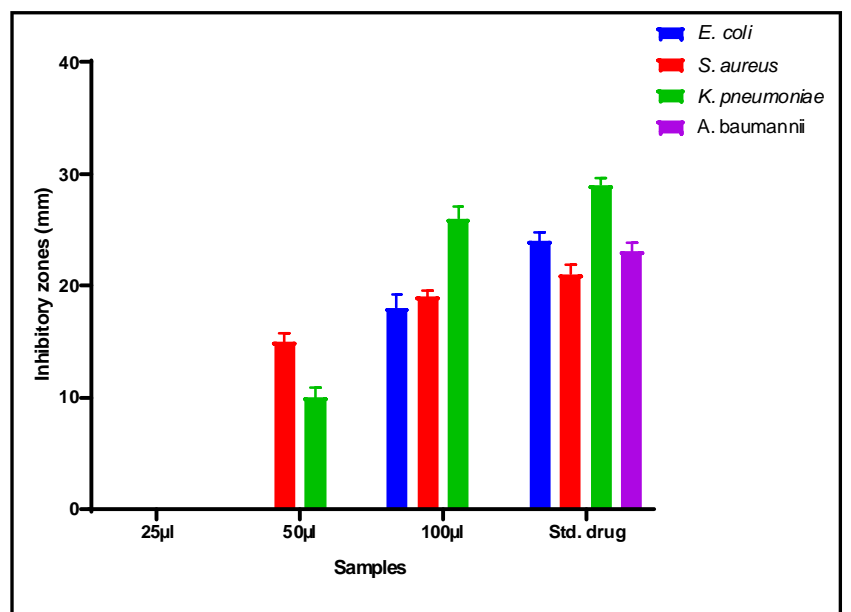

Figure 26: Antibacterial activity of beejakarishta of 20 days fermentation sample in summer season.

\subsection{Limewater test}

This test showed positive result for $5^{\text {th }}$ and $11^{\text {th }}$ day samples and negative results for $21^{\text {st }}$ day sample in summer season and autumn fermentations. In winter season, it was negative in $5^{\text {th }}$ and positive in $11^{\text {th }}$ and $21^{\text {st }}$ day. A positive test resulted when lime-water turned milky. It is due to the reaction of calcium hydroxide with carbon dioxide to form calcium carbonate which is insoluble in water and, thus forms a milky turbid appearance

\subsection{Organoleptic characters}

\subsubsection{Appearance}

The samples were found to be thick liquid on $0^{\text {th }}$ day and frothy liquid on $5^{\text {th }}$ day and on $11^{\text {th }}$ day. On $21^{\text {st }}$ day, the samples were less frothy except samples on winter season.

\subsubsection{Odor}

No alcoholic smell was identified on $0^{\text {th }}$ day. This indicates the initiation of fermentation. Alcoholic smell was felt on $11^{\text {th }}$ day and the smell became intense on $21^{\text {st }}$ day. 


\subsubsection{Taste}

On $0^{\text {th }}$ day, the taste of the samples was found to be sweet, astringent and bitter. The fermentation has changed the taste to alcoholic on $5^{\text {th }}$ and $11^{\text {th }}$ day. The alcoholic taste was higher on $21^{\text {st }}$ day.

\subsubsection{Color}

The color of the samples was found to be dark reddish brown on $0^{\text {th }}$ day. There was no color change observed during fermentation on $5^{\text {th }}$, $11^{\text {th }}$ and $21^{\text {st }}$ day.

\subsubsection{Touch}

The samples were found to be sticky and thick on $0^{\text {th }}$ and $5^{\text {th }}$ day, on $11^{\text {th }}$ day, the samples in summer season were observed to be thinner and sticky. The samples on $21^{\text {st }}$ day were found to be thinner and less sticky.

\subsection{Analytical study}

\subsubsection{Temperature}

The room temperatures were found to be $33^{\circ} \mathrm{C}$ for summer season, $30^{\circ} \mathrm{C}$ for autumn season and $26^{\circ} \mathrm{C}$ for winter season. The temperature had slight variation after fermentation for 10 and 20 days. This shows that external climate affects the fermentation process by altering the temperature (Figure 9). Optimum temperature in the range of $20-35^{\circ} \mathrm{C}$ is suitable for initiation of fermentation. The growth rate of yeast cells is strongly influenced by fermentation temperature. The rate of fermentation is slowed down in cooler temperatures as they prolong the lag phase. At low temperatures, yeasts tend to be less sensitive to the toxic effects of high alcohol concentration. In the case of different yeasts, the higher (warmer) temperatures, a rapid decrease in cell viability is noticed. When the temperature is becoming very high, the functions of enzymes and the integrity of membranes are affected, which could result a halt in the fermentation process. But, in fact, the optimum temperatures for different yeast fermentations will vary as various strains respond in different ways to temperature.

\section{$3.7 .2 \mathrm{pH}$}

The $\mathrm{pH}$ of the samples varied between $4.02 \pm 0.16$ to $4.27 \pm 0.05$. The $\mathrm{pH}$ was low for $\mathrm{BAG}_{20}$ and highest was observed for $\mathrm{BASt}_{20}$ and $\mathrm{BASi}_{10}$. Figure 10 shows the $\mathrm{pH}$ of the samples used in the study. $\mathrm{pH}$ affects the shape of proteins in yeast cells which are responsible for the metabolic processes whereby fermentation. Each strain of yeast has an optimal $\mathrm{pH}$ range but most are in the range of 4 to 6 . The initial $\mathrm{pH}$ is observed within this range, so it favored the imitation of fermentation. The reduction is more in summer season and less in autumn season. The $\mathrm{pH}$ may decrease during fermentation due to the production of carbonic acid $\left(\mathrm{CO}_{2}\right.$ dissolved in water) and other organic acids like gallicacid, citricacid, ascorbic acid, etc. Also, alcohol produced by fermentation may be another reason.

\subsubsection{Specific gravity}

The specific gravity of the samples varied between $1.259 \pm 0.00$ to $1.29 \pm 0.00$. The specific gravity was low for $\mathrm{BAG}_{20}$ and highest was observed on $\mathrm{BASt}_{10}$. Figure 11 shows the specific gravity of the samples used in the study. This lowering may be due the breakdown of sugars into alcohol. By 20 days, more sugars may be converted to alcohol than 10 days and also the rate of breakdown may be less in autumn season, and more in summer season.

\subsubsection{Total solids}

Total solids content includes solid matter which is suspended, dissolved, or settled in a liquid, and are left after evaporation and drying of a sample. The total solids suspended in the samples varied between $63.66 \pm 0.57$ to $69 \pm 1.00$. The specific gravity was low for $\mathrm{BAG}_{20}$ and highest was observed for BASt ${ }_{10}$. Figure 12 shows the total solids of the samples used in the study. Total solids decreased by increasing duration of fermentation. summer and autumn sample shows more reduction on $20^{\text {th }}$ day than winter samples.

\subsubsection{Brix}

The degree of brix in the samples varied between $55 \pm 1.00$ to $59 \pm$ 1.00. The brix was low on $\mathrm{BAG}_{20}$ and highest was observed on BASt $_{10}$. Figure13 shows the brix of the samples used in the study.

\subsubsection{Alcohol content}

The alcohol content in the samples varied between $2.13 \pm 0.46$ to $6.98 \pm 0.94$. The alcohol production was low on $\mathrm{BASi}_{10}$ and highest was observed on $\mathrm{BAG}_{20}$. Summer season samples had more alcohol content. Figure 14 shows the alcohol content of the samples used in the study. On comparison, the formation of alcohol is more in summer samples and less in winter samples.

\subsubsection{Total sugar}

The total sugars present in the samples varied between $36.53 \pm 2.44$ to $56.66 \pm 2.3$. The total sugar was low on $\mathrm{BAG}_{20}$ and highest was observed on $\mathrm{BASi}_{10}$. Total sugar is reduced from $11^{\text {th }}$ day to $21^{\text {st }}$ day. The reduction is more in summer season samples. Figure 15 shows the total sugars present in the samples used in the study. Total sugars comprise all mono-and disaccharides which are reducing and non-reducing sugars. It was seen that total sugar is reduced in 20 days sample than 10 days sample in all the 3 seasons.

\subsubsection{Reducing sugar}

The total sugars present in the samples varied between $25.16 \pm 1.2$ to $33.12 \pm 1.75$. The reducing sugar was low on $\mathrm{BAG}_{20}$ and highest was observed on $\mathrm{BASi}_{10}$. Reducing sugar is reduced from $11^{\text {th }}$ day to $21^{\text {st }}$ day. The reduction is more in summer seasonsamples. Figure 16 shows the reducing sugars present in the samples used in the study.

\subsubsection{Non-reducing sugar}

The non-reducing sugars present in the samples varied between 9.33 \pm 3.41 to $23.54 \pm 0.95$. The non-reducing sugar was low on $\mathrm{BAG}_{10}$ and the highest was observed on $\mathrm{BASi}_{10}$. Figure 17 shows the nonreducing sugars present in the samples used in the study.

\subsubsection{Total acidity}

The total acidity of the samples varied between $0.67 \pm 0.02$ to 1.24 \pm 0.08 . Figure 18 shows the total acidity of the samples used in the study. The overall track analysis is graphically represented in Figure 19.

\subsubsection{HPTLC analysis}

The HPTLC profiling, which was performed as described elsewhere in this report, using methanol sample solvent system, generated the results as shown Table 4, Figures 20, 21 indicate the Rf values, peaks and area percentage of samples. 


\subsubsection{Antibacterial analysis}

Beejakarishta of 20 days fermentation in summer season $\left(\mathrm{BAG}_{20}\right)$ is used for antibacterial analysis. Three concentration $(25 \mu 1,50 \mu 1$, $100 \mu \mathrm{l})$ of samples were used. Table 5 shows the inhibitory zones of the $\mathrm{BAG}_{20}$ against hospital acquired pathogens. $100 \mu \mathrm{l}$ of $\mathrm{BAG}_{20}$ showed significant antibacterial activity against Escherichia coli $(18$ $\mathrm{mm})$, Staphylococcus aureus $(19 \mathrm{~mm})$ and Klebsiella pneumoniae $(26 \mathrm{~mm})$. No inhibitory zones were obtained for Acinetobacter baumannii (Figures 22 to 26).

\section{Discussion}

The effectivity and efficiency of the antibiotics in use currently are being challenged greatly by the emergence of MDR bacterial strains. Moreover, the indiscriminate worldwide overuse and misuse of antibiotics is the major reason for the high rates of microbial resistance. A study estimates that about 33000 people die each year as a direct consequence of an infection due to bacteria resistant to antibiotics and that the burden of these infections is almost equal to the adverse effect of tuberculosis, influenza and HIV/AIDS combined. World Health Organization (WHO) had declared antimicrobial resistance (AMR) as an emerging crisis in the world and there is need for the development of new antimicrobial agents/therapies to overcome AMR (Aslam et al., 2018). The present study focuses on development of beejakarishta at different conditions and evaluating its antibacterial activity against hospital acquired pathogens.

Beejakarishta mentioned in charakasamhitha is taken for the present study. Various references of beejakarishta was compiled and an attempt is made to understand the differences in the ingredients and preparation (Acharya Vaidya Jadavaji Trikamji, 2002 - 1). And all the ingredients including asana, which is the which is the major ingredient of beejakarishta (Acharya Vaidya Jadavaji Trikamji, 2002 -2) were taken as described in charakasamhitha.

The name of yoga got from its synonym Beejaka. Acharya charaka included asana in 20 sarasava yoni Hareethaki and Amalaki included in 26 phalasava yoni.Vaghbhtachraya enumerated Draksha in 5 madya yoni and considered as best among them. Lac is the only animal origin resin used in Ayurveda. These kwathadravyas are pharmacologically and therapeutically much important in the Beejakarishta yoga as they are the main drugs. Most of them shows action in rasa raktha and medovahasrotas, kaphapithahara or sarvadoshaharakarma, rasayanaguna. Out of six, 4 are included in asava yoni. It may refer to the important of their asavarishta preparation (Acharya Vaidya Jadavaji Trikamji, 2002 - 2).

Therefore, the analysis of six samples of beejakarishta which were prepared in triplicates showed that, change in season affects the fermentation and physiochemical parameters varies. This confirms that temperature has a great impact in affecting the fermentation and altering its nature (Kushwaha Singh Chandra Harish,2011). Furthermore, the samples were subjected to HPTLC analysis to differentiate the bioactive compounds present in it. Several compound peaks were observed and specific peaks were observed in certain samples (G-20, ST-10 and SI-20). This indicates the, seasons play a vital role in affecting fermentation and deviation in bioactive compounds was pronounced (Murthy Srikantha, 2009). Moreover, the chemical compounds corresponding to the peaks need to be identified. Due to lack of existing references, we cannot compare the values to identify the compounds. Further studies have to be done for the identification of the compounds using higher techniques. The $\mathrm{BAG}_{20}$ showed significant properties; hence it has been evaluated for antibacterial activity against hospital pathogens.

Praveen et al. (2010) investigated the antibacterial activity of four arishtas, namely; Chandanasava, Vidangarishta, Kanakasava and Pippalyasava against $S$. aureus and E. coli. S. aureusare more susceptible than E. coli. Among the formulation evaluated, Vidangarishta showed higher inhibition of E. coli followed by Kanakasava, Chandanasava and Pippalyasava. Vidangarishta had higher inhibition of S. aureus followed by Kanakasava, Chandanasava and Pipalyasava.

Ayurvedic herbal formulations which are widely used in ayurvedic medicine in treatment of various infectious diseases were investigated for antibacterial efficacy by Tambekar and Dahikar (2010). The antibacterial activity was determined against 10 enteric pathogenic bacteria. The results showed that bilba churna, chandanadi churna, pushyanug churna and amlachurna were effective against Staphylococcus epidermidis, Staphylococcus aureus, Proteus vulgaris, Escherichia coli, Salmonella typhi and Pseudomonas aeruginosa. These results well correlate with the present study. It is also confirmed that these herbal formulations can be used not only as a health supplement but also for treatment and control of antibacterial infection.

\section{Conclusion}

The present study concentrates on determining the pharmaceutico analytical study of beejakarishtaon variation in seasons (sandhana kala). In this study, six samples are made in Summer season, autumn season and winter season with 10 and 20 days duration of fermentation. Out of the 6 samples, 3 samples were kept for 10 days fermentation and other 3 for 20 days' fermentation. Fermentation tests and physicochemical analysis were performed. Beejakarishta of 20 days' fermentation in summer season $\left(\mathrm{BAG}_{20}\right)$ is used for antibacterial analysis. $100 \mu 1$ of $\mathrm{BAG}_{20}$ showed significant antibacterial activity against E. coli, S. aureus and $K$. pneumoniae. Therefore, the developed Beejakarishta of 20 days' fermentation in summer season can be used for development of antibacterial drugs for treatment of multidrug resistant (MDR) bacterial infection.

\section{Acknowledgements}

The authors are grateful to the Deanship of Scientific Research, Prince Sattam bin Abdulaziz University, Al-Kharj, Saudi Arabia for its support for this research work.

\section{Conflicts of interest}

The authors declare that there are no conflicts of interest relevant to this article.

\section{References}

Acharya Vaidya Jadavaji Trikamji, (2002-1). Charak samhita with commentary of cakrapanidatta and sutra sthana. Chowkhamba Sanskrit Series, pp:30.

Acharya Vaidya Jadavaji Trikamji, (2002-2). Charak samhita with commentary of cakrapanidatta and sutra sthana. Chowkhamba Sanskrit Series, pp:131.

Aslam, B. (2018). Antibiotic resistance: a rundown of a global crisis. Infect. Drug Resist., 11:1645-1658. https://doi.org/10.2147/IDR.S 173867. 
Elbossaty, W.F. (2017). Antibiotic drugs and multidrug resistance bacteria Int. J. Pub. Health Safe, 2:2-4.

Harisankar Pandey (1993). Asava-arishtavijnana by Vaidhyabhushan Pt. Pawani Prasad Pharma, Chaukamba Krishnadas Academy, Varanasi, pp:96.

Krishnamurthy (1973). Susruthasamhitha with English translation, Vol-1, Chauwkhamba Orientalia, Varanasi. pp:363.

Kushwaha Singh Chandra Harish (2011). Commentary: Ayurveda Deepika of Chakrapani on Charaka Samhitha of Charaka and Chikitsasthana,

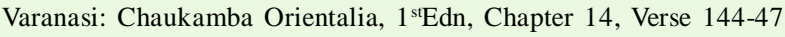
Vol 2. pp:362.

Murthy, K.R. Srikantha (2009). Astanga Hrdayam of Vagbhata -

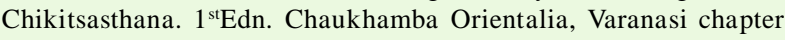
10, Verse 47-50. Vol 2. pp:362.

Parasurama Sastri (2008). Sharangdharasamhita of Sharangdhara pradhamakhanda, chapter $1 / 51,7^{\text {th }}$ Edn. Varanasi: Chaukhamba Orientale. pp:13.

Praveen Kumar, S.V. (2010). Antibacterial and anthelmintic activity of selected fermented Ayurvedic herbal formulations. Drug Invention Today, 2(7):347-348.
Rajesh, T. (2014). Evaluation of antimicrobial activity of different herbal plant extracts. International Journal of Pharmaceutical Sciences and Research, 5(4):1460-1468.

Sharma Ram Anant (2012). SushruthaSamhitha of Susrutha. Utharasthana, ChaukambaOrientalia, Varanasi, 1st Edn. Vol-3, chapter 42, Verse 46-49. pp:338.

Sir Monier-Williams (1899). An English Sanskrit dictionary - Etymologically and philologically Arranged with special reference to cognate Indo-European languages, MotilalBanarsidass Publishers Pvt. Ltd, Delhi, pp: 1144.

Sre Ganga SahyaPandeya (2003). Gadanigraha of Sri Vaidya Sodhala A.M.S. Vidyotini Hindi Commentary, IndradevaTripati, Chaukamba Sanskrit series, Varanasi, $4^{\text {th }}$ Edn, pp:376.

Tambekar D.H. and Dahikar S.B. (2010). Antibacterial potential of some herbal preparation: An alternative medicine in treatment of enteric bacterial infection. Int. J. Pharm Sci., Vol-2, Suppl-4, pp:176-179.

Visvanatha Dvivedi Shastri (2002). Bhavaprakasha Nighantu, Motilal Banarsidass Publishers Private Ltd., Delhi, $9^{\text {th }}$ Edn, pp:457.

Yadavji Trikamji Acharya (1983). Dravyagunavijnanam, sixth Edition, Nagpur, Baidyanath Ayurveda Bhavan Limited. pp:218-228.

K.P Shamna, A.K. Muraleedharan and Muhammad Musthafa Poyil (2021). Standardization of beejakarishta 